\title{
Homogeneous Distribution of Escherichia coli Measured within the Vertical Water Column of Small, Freshwater Streams
}

\author{
David. W. Buckalew ${ }^{1}$, Albert. J. Tuono ${ }^{1}$, Amanda. K. Simmons ${ }^{1}$, Travis. W. Lankford ${ }^{1}$, \\ Donald. H. Smith ${ }^{2}$ \\ ${ }^{1}$ Department of Biological and Environmental Sciences, Longwood University, Farmville, VA, USA \\ ${ }^{2}$ Virginia Department of Environmental Quality, Richmond, VA, USA

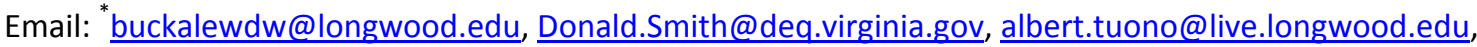 \\ amanda.simmons@live.longwood.edu, travis.lankford@live.longwood.edu
}

Received 1 December 2014; accepted 24 March 2015; published 26 March 2015

Copyright (C) 2015 by authors and Scientific Research Publishing Inc.

This work is licensed under the Creative Commons Attribution International License (CC BY). http://creativecommons.org/licenses/by/4.0/

(c) (i) Open Access

\begin{abstract}
Sampling for coliform bacterial indicators such as Escherichia coli (E. coli) provides a universally accepted gauge of the microbiologic quality of fresh surface waters worldwide. Protocols for the capture, preservation, and analysis of indicator bacteria collected from moving waters (e.g., rivers, streams, canals, etc.) parallel those for collecting bacteria from standing waters (e.g., ponds, lakes, and impoundments). Strict depth- and width-integrated rules established for testing moving waters are likely a result of the historical precedence of our knowledge of bacterial stratification in standing waters. Sampling protocols for indicator bacteria in freshwater streams recommend capture and retrieval of samples from the mid-water column directed into the current and within the deepest portion of the channel to prevent collection of either benthic particles or surface films. Chi-square analyses of multiple stratified samples captured on the same date and time reveal that variability in sampling position at specified depths within the main stream column or within randomly chosen locations within the main stream channel has no effect $(p \geq 0.25)$ upon such indicator bacteria numbers. Additionally, these data are the first to show that concentrations of the common bacterial indicator, $E$. coli, are homogeneously distributed throughout both lateral area and vertical water column within/near a single sampling location of a moving water body up to 245 cubic feet per second (cfs) discharge. Moreover, one data point (bacterial sample) appears to represent the overall bacterial concentration of a small freshwater stream obtained from any single sampling location within/near the main channel for a given date and time. These findings suggest some latitude in sampling strategies for assessing small freshwater streams for indicator bacteria such as $E$. coli for workers in both environmental and public health fields.
\end{abstract}

\footnotetext{
"Corresponding author.
} 


\section{Keywords}

\section{Indicator Bacteria, Stratification, Water Monitoring, E. coli}

\section{Introduction}

Detection of Escherichia coli (E. coli) in natural freshwater bodies is used as an indicator of fecal contamination in assessing environmental water quality worldwide. Such indicators positively correlate with fecally-derived pathogens (e.g., Salmonella, Campylobacter, Giardia, enteric viruses, etc.) and have been used by both public and private environmental monitoring agencies for the last 100 years.

\subsection{Studies of Indicator Distribution in Natural Waters}

To date, many reports have been published on the vertical and horizontal variation of $E$. coli density and other indicator bacteria within standing water bodies such as freshwater lakes, reservoirs, and water/sewage treatment ponds. Environmental parameters such as temperature, oxygen, and/or nutrient availability [1]-[4], sediment deposits [1] [5]-[7], solar inactivation and insolation [8]-[10], predation [3], presence of biological host(s) [11]-[13], input from watershed soils and sediments [14] [15], nucleic acid content [16], and variety of bacterial indicator assessed [17] have been examined with respect to depth in water column in these water bodies. Still other reports have examined stratification of viral populations in freshwater lakes [18] and estuaries [19].

Although there exists information about bacteria stratification in lakes [4] and a recent study of estuarine water reports variation in E. coli numbers with respect to lateral location and bank side [20], distributions of $E$. coli and/or other indicator bacteria in freshwater streams and rivers (i.e., moving freshwater bodies) have received little attention [4]. Perhaps the main reason for the lack of such data is due to the early adoption of standard field techniques for the capture of stream samples that mirrored protocols used for capture of standing water. Furthermore, because of the association of bacteria and suspended sediment, standardized techniques for the collection of water quality data have been published for sampling streams and/or flowing water sites according to rigorous protocols for suspended sediment analysis [21]-[23]. The purpose of such standards is to: 1) provide methods to minimize bias within and between data sets; 2) provide reproducible data; 3) encourage consistent field sampling methodology for data comparisons; and 4) provide citable documentation of data collection protocols to reinforce all the above. The philosophy of standardized water capture is to achieve consistency from one sampling event/date to the next.

\subsection{Historical Perspective on Sampling for Indicator Bacteria}

In 1965, early microbial ecologist A.G. Rodina stated "the selection of sampling locations in water mass is an important task which must be performed with all possible care" [24]. Sampling flowing water for microbial presence requires sufficient sample size to adequately represent the material sampled, yet reduced volume to allow both efficient transport and preservation of sample quality. Bacterial presence in flowing waters is measured from selected points or sampling sites along the drainage. Higher numbers of bacteria tend to be associated with warm months, proximity to point source contributors (e.g., wastewater plants, agricultural operations, storm drains, etc.), and storm runoff [5] [25]. Depth- and width-integrated approaches to sampling moving waters are difficult, especially in streams with low depth and velocities [23]. Therefore, in smaller streams, catch- or grabsamples can be obtained by hand from the main channel at mid-depth [24] with the understanding that any departure from standardized technique should be based on sound field judgment and be quality-assured, and documented.

\subsection{The Dilemma of Obtaining a "Representative" Sample}

Scientists and technicians within the public and private water monitoring community grapple with the fact that streams and other moving water bodies present a dynamic medium from which to obtain a representative sample for bacterial assessment for either surveillance or regulatory purpose. In spite of published standard methodologies, stream hydrography can change between sampling periods, reducing sampling precision as vertical (depth) 
and horizontal position of the main stream channel varies. Accordingly, in an attempt to obtain representative bacterial counts for a sample site, environmental regulatory agencies suggest taking multiple samples during a prescribed time to obtain an average or geometric mean for the location.

So the question remains: As care is taken to sample for bacteria in a stream, the question of variability in bacterial concentration for any one sampling site, regardless of depth or lateral location, remains to be examined. To our knowledge, these data are the first to address this question within a moving freshwater body.

\subsection{The Experimental Question}

This study examines the differences between counts of $E$. coli indicator bacteria from samples obtained at different points within the vertical and lateral water columns of four freshwater streams in the upper Appomattox River watershed in the Piedmont region of central Virginia. It represents one of the first reports in the literature examining bacterial numbers within the potentially stratified water column of a moving water body. The results provide critical information and implications relative to standard stream sampling protocols for water quality technicians and scientific professionals within the field of water quality assessment, specifically, and for environmental microbiologists, in general.

\subsection{Objectives}

The primary objective of this study was to determine whether or not the standard bacterial sampling protocol utilized and approved by most environmental agencies (e.g., Virginia Department of Environmental Quality [VA-DEQ] or United States Environmental Protection Agency [USEPA]) provided a representative count of bacterial concentrations within peripheral locations (both vertical and lateral) at a designated stream collection site. A secondary objective was to determine if numbers of $E$. coli indicator bacteria varied within the vertical and lateral water column of a moving freshwater stream at a given time and place.

\section{Material and Methods}

\subsection{Sampling Locations}

Weekly water samples were taken during the spring and fall months for two successive years from four different stream sites (labeled as APP1, APP2, BUF1, and VAU14) in the upper Appomattox River watershed within Buckingham, Cumberland, and Prince Edward counties in central Virginia ( $\mathrm{n}=936$ samples). The sampling sites are located within a 15-mile radius of the town of Farmville, Virginia (Figure 1). The streams reveal aver-

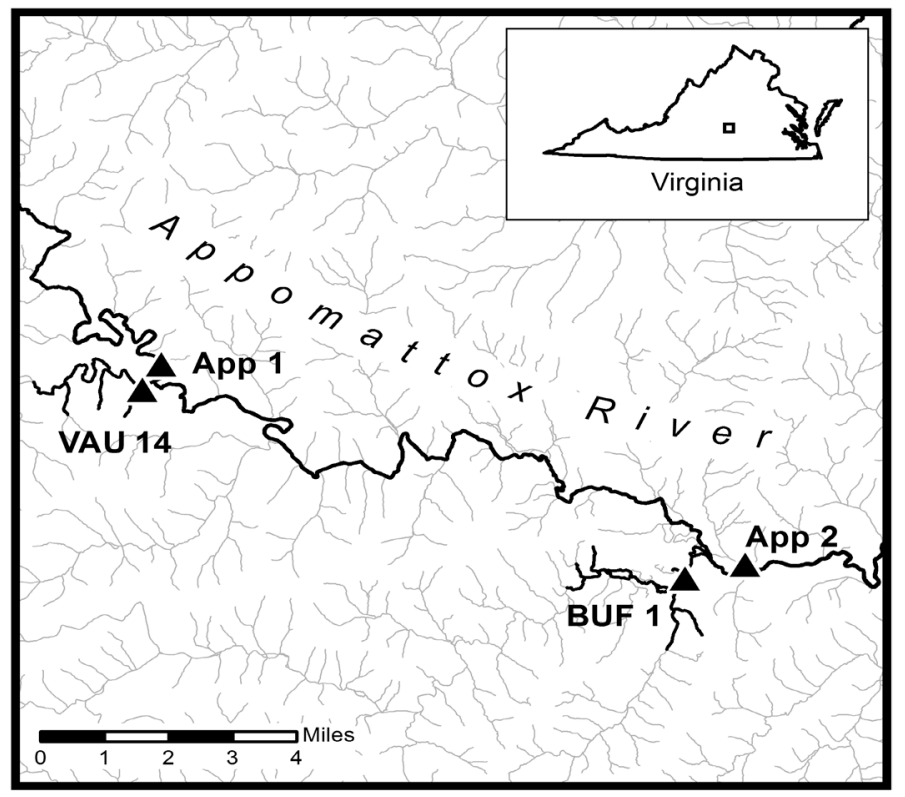

Figure 1. Map of water sampling sites within central Virginia, USA. 
age depths between $0.3 \mathrm{~m}$ and $1.5 \mathrm{~m}$ at baseline flow and 10-year average discharges of $\leq 245 \mathrm{cfs}$. Geographically, all sample sites are classified as second order streams with the exception of the APP2 location, which is on a third order section of stream. Stream site locations with GPS coordinates are presented in Table 1. For all sampling locations, the predominant land use of the sub-watersheds is agricultural (beef, dairy, poultry, row crops, and hay fields) interspersed with mixed hardwood forest and low housing density.

All four stream sampling sites are located at highway bridge access points. At each stream site for each sample date, three mid-column water samples were obtained within the deepest channel of the stream from the bridge perch that spanned the stream (identified as "bridge" samples). In addition, three replicate water sample sets were obtained within a $50 \mathrm{~m}$ distance upstream of the bridge from randomly chosen locations both within or peripheral to the main channel and assessed for bacterial numbers from each of three depth locations (high, mid, and low water column).

\subsection{Sampling Protocol}

At each site for each sample date, three separate samples were obtained from a bridge perch via a weighted, surface sterilized, tethered stainless steel cylinder (similar to a dip sampler) holding a sterile $120 \mathrm{~mL}$ polystyrene clinical sample container (NCS Diagnostics, Etobicoke, Ont.) and lowered to mid-column in the deepest channel of the stream. In addition, three separate sets of stratified water samples were taken within $50 \mathrm{~m}$ upstream of the bridge via hand grab method including: upstream-high column (water sample taken at $2.5 \mathrm{~cm}$ below stream surface), upstream-mid column (water sample taken at mid-column in stream), and upstream-low column (water sample taken at $2.5 \mathrm{~cm}$ above stream bottom). The stratified water samples were obtained facing upstream at three random but separate locations in succession, moving upstream of the bridge perch (Figure 2). Care was taken to obtain stratified samples at the specified depth using a meter stick placed in the water as a guide (Figure 3). In each case, a closed sample bottle was submerged to the measured depth, pointed into the current and

Table 1. Water sampling sites with coordinates within the upper Appomattox River watershed in central Virginia.

\begin{tabular}{ccc}
\hline Sampling Site & Location (Lat./Long.) & VA County \\
\hline Appomattox River 1 (App 1) & $37.358494 \mathrm{~N} / 78.554715 \mathrm{~W}$ & Buckingham/Prince Edward \\
Appomattox River 2 (App 2) & $37.307314 \mathrm{~N} / 78.389130 \mathrm{~W}$ & Cumberland/Prince Edward \\
Buffalo Creek (BUF 1) & $37.303798 \mathrm{~N} / 78.406167 \mathrm{~W}$ & Prince Edward \\
Vaughan's Creek (VAU 14) & $37.352005 \mathrm{~N} / 78.560084 \mathrm{~W}$ & Prince Edward \\
\hline
\end{tabular}

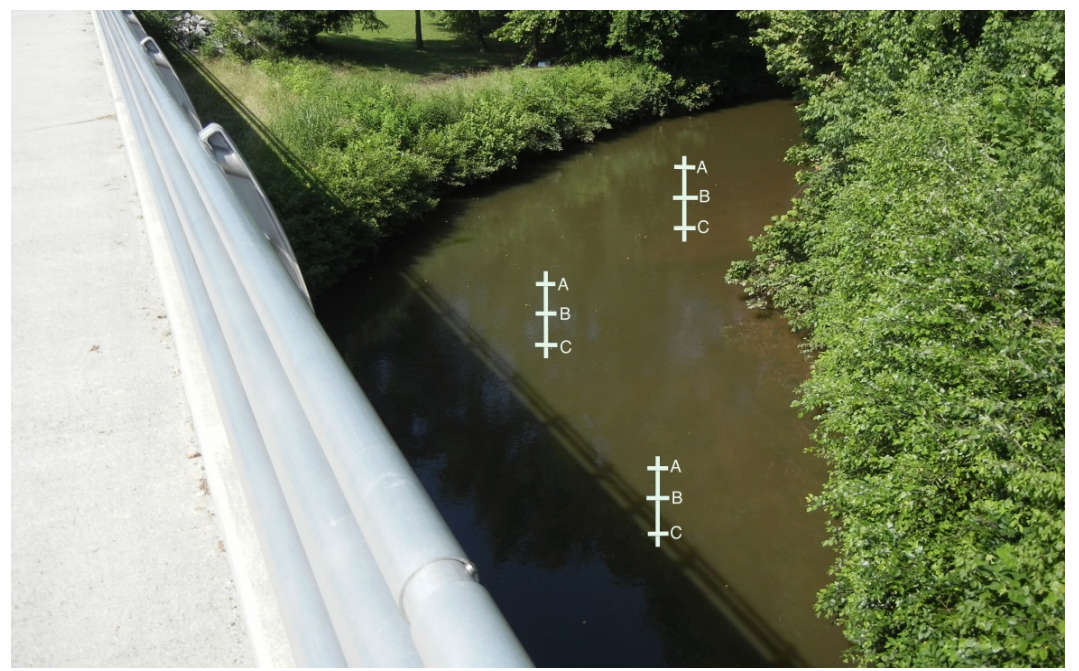

Figure 2. Photo showing three random sampling locations within $50 \mathrm{~m}$ upstream of representative bridge perch (APP2 site) showing three random upstream locations where separate sets of stratified water samples were taken $(\mathrm{A}=$ high column, $\mathrm{B}=$ mid column, $\mathrm{C}=$ low column) within the stream water column. Three mid-column samples from the main stream channel were also obtained from the bridge perch. 


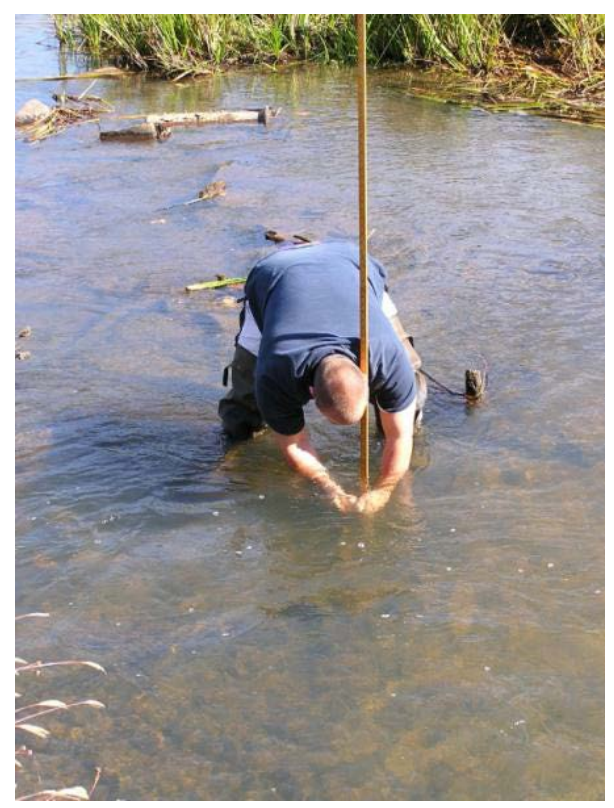

Figure 3. Capture of stratified water samples showing the use of a meter stick while opening sample bottle facing upstream and towards the water current.

opened briefly to allow entry of water to ensure clean capture of water. All water samples were captured in separate sterile sample containers, capped tightly, and immediately submerged in ice for transport back to the laboratory to be assessed for bacterial concentration using the Colilert ${ }^{\circledR}$ defined substrates (IDEXX, Westbrook, ME) medium for enumeration of total coliforms and E. coli.

\subsection{Laboratory Analysis}

All samples were aseptically processed within the laboratory for bacterial analysis within three hours of sampling in accordance with APHA guidelines [26]. Coliform bacteria and E. coli were assayed using Colilert Quanti-tray $2000^{\circledR}$ envelopes (IDEXX, Westbrook, ME) with a 25\% sample dilution (25 mL test sample: $75 \mathrm{~mL}$ sterile phosphate buffered dilution water) according to manufacturer's directions, and incubated at $44.5^{\circ} \mathrm{C} \pm$ $0.2^{\circ} \mathrm{C}$ for $24 \pm 2 \mathrm{hrs}$. For this analysis, only counts of $E$. coli were used for comparison. One sample blank was pro- cessed with each sampling date cohort to ensure sterility of dilution water. After incubating, wells showing chromogenicity (yellow) and fluorescing under long UV (365 nm) illumination were counted positive for E. coli. All enumerations were performed using a most probable number (MPN)-based system with a quantification range between $<1$ and $9676 \mathrm{CFU}$ per $100 \mathrm{~mL}$ when using a $25 \mathrm{~mL}$ sample dilution. Weekly aliquots of several randomly selected Quanti-tray wells showing both chromogenic and fluorogenic responses were aseptically transferred using sterile, disposable 3 cc medical syringes to confirm lactose fermentation into lactose broth (EC broth, BDL, Sparks, MD) and to check IMViC responses (broth/agar media-DIFCO Labs, Detroit, MI). Confirmation of $E$. coli is enhanced by IMViC testing accompanied by the elevated $\left(44.5^{\circ} \mathrm{C}\right)$ incubation temperature [27]. All wells presumed to contain E. coli were confirmed as positive. Recent data in this and other labs [28] [29] indicate confirmatory tests are not needed when using the Colilert medium on freshwater samples. Colilert test results were recorded as number of total coliform bacteria (not reported in this study) and as number of $E$. coli per $100 \mathrm{~mL}$ for all data points.

\subsection{Statistical Analysis}

Counts of bacterial "colony forming units" per $100 \mathrm{~mL}$ (CFU/dL) of ambient water sample are generally believed to be variable among both field duplicate samples and sample or laboratory quality assurance (QA) duplicates ("splits"). The experimental design of our study violates a fundamental assumption of parametric analysis of variance (ANOVA) - the independence of measurements [30]. Samples that are collected within minutes of one another from various locations at the same field site are not independent; the samples are expected to be re- 
lated, if not identical in a statistical sense. However, there are no published data that test this assumption involving bacterial assays, and most microbiologists and field technicians believe bacterial counts from such samples to be different (personal communications).

\subsubsection{Experimental Treatments}

The range of treatments for each sampling event in this study include: 1) Bridge-Mid samples (obtained from the bridge perch via weighted sampling device submerged to mid water column), and within-stream samples composed of 2) Upstream-High or near-surface channel samples (obtained by hand at $2.5 \mathrm{~cm} \mathrm{depth),} \mathrm{3)} \mathrm{Upstream-}$ Mid or mid-depth channel samples (obtained by hand at mid-depth in water column), and 4) Upstream-Low or near-bottom channel samples (obtained by hand at $2.5 \mathrm{~cm}$ from bottom substrate).

\subsubsection{Experimental Blocks}

Three replicate samples were collected for each of the four treatments at one sampling site $(n=12)$ for each sampling event or date. This statistical analysis groups data by site and sampling event to ensure comparison of homogenous data, and for logical reasons, disregards data comparisons between sites or sampling events.

\subsection{Nested ANOVA}

After the first year of data was recorded, variance components of bacterial counts were evaluated across 37 sampling events (site-date combinations), across four locations per event (bridge, high, mid, low), with three replicates per location $(n=444$ samples) using a two-level nested parametric analysis of variance. All bacterial counts were log-transformed $\left(\mathrm{X}^{\prime}=\log _{10}[\mathrm{X}]\right)$ prior to the analysis. Because no zero bacterial counts were observed, the standard modified log-transformation $\left(X^{\prime}=\log _{10}[X+1]\right)$ was not required.

\subsection{Friedman One-Way ANOVA}

Subsequent to the results of the parametric analysis, we continued sampling with the same experimental design through the second year to increase the sample size at each site (i.e., to increase the number of blocks). A second phase analysis was then applied individually to each study site using the non-parametric Friedman one-way ANOVA based on ranks. The Friedman test is a non-parametric analysis of variance designed for making comparisons among several related samples, such as the results of different "treatments" (in this case, Bridge-Mid, Upstream-High, -Mid, and -Low samples) applied within "blocks" (date/site combination) or groups of experimental units that are similar in type. Its outcome is based on comparison of ranks of measurements within each complete block and is especially appropriate when comparisons between blocks are not of interest or are not possible [31]. A slight modification of the Friedman procedure, as described by Conover [31], was applied to the replicated within-block measurements of the current study. Again, each sampling event (site/date combination) is considered as a block, and the various sampling depths and/or locations within a site are analogous to treatments.

All calculations were carried out on Excel spreadsheets using formulas from Conover [31] and standard Excel functions. In the case of tied measurements, each of the tied observations was assigned the mean rank of the tied group; the "RANK" (number, ref, order) function in Excel assigned the lowest rank to all members of tied groups.

\section{Results}

\subsection{Pooled Data Comparisons}

Pooled means ( \pm std. dev.) of $E$. coli counts obtained from each of the treatment depths for each sampling location are presented in Figure 4. Although two of the sampling locations (APP1 and VAU14) contained comparatively lower bacterial concentrations, both the mean and variability of $E$. coli counts remained uniform across sample depths ( $\mathrm{p}>0.5)$. Likewise, the sampling sites that revealed higher concentrations of $E$. coli (APP2 and BUF1) showed no differences ( $p>0.5$ ) with respect to mean or variability across sample depths. The relatively high variability in bacterial counts from each sample site (Figure 4) was due to sampling dates occurring on/ near precipitation events as well as during dry periods which generally corresponded to higher and lower bacterial counts, respectively. 


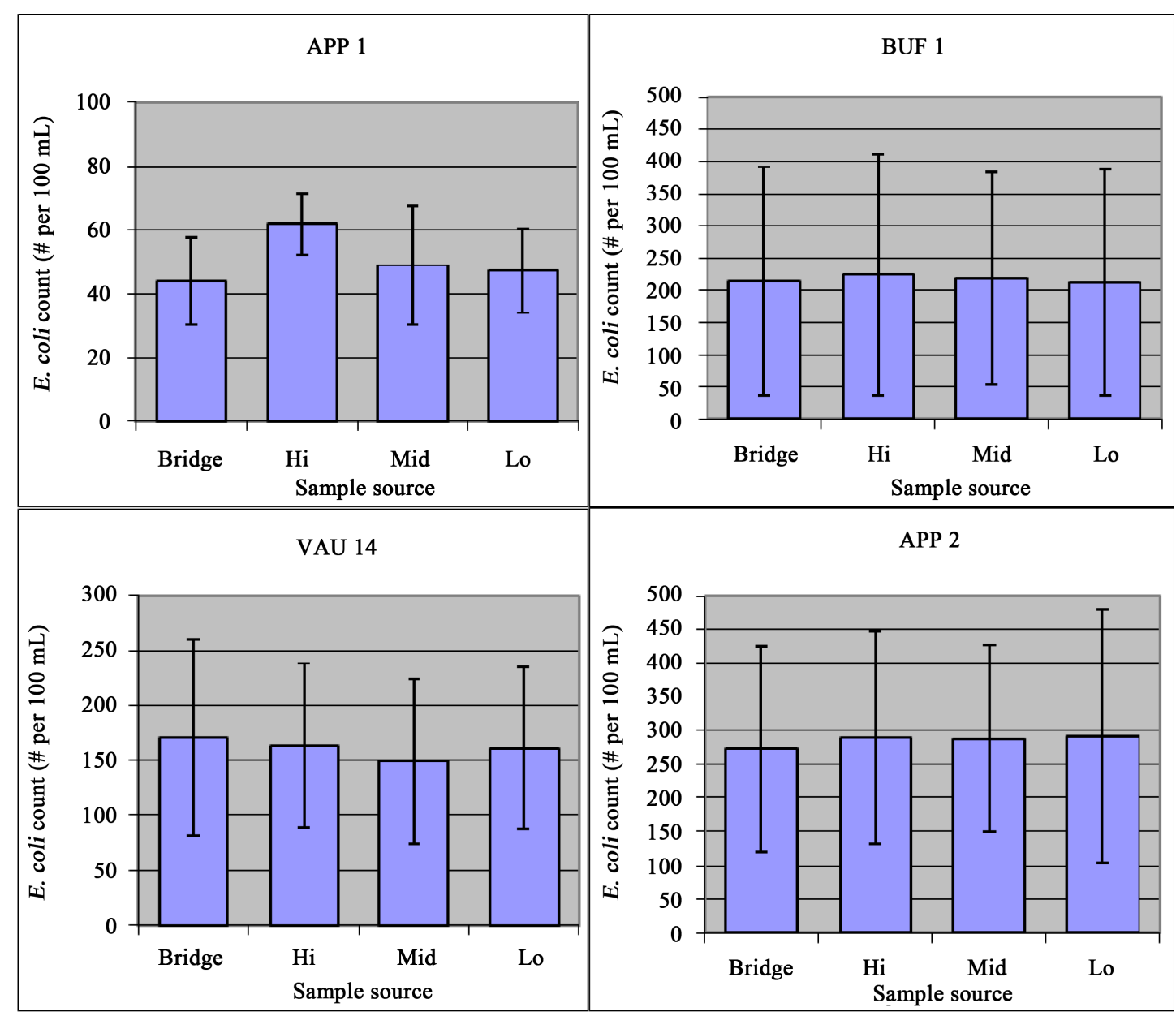

Figure 4. Pooled mean data. Mean \pm std. dev. of pooled $E$. coli counts at different depths within the water column from each of the four water sampling sites revealed no differences $(\mathrm{p}>0.5)$ either within the cleaner (APP 1 and VAU 14) or more contaminated (APP 2 and BUF 1) sampling sites. Note: "Bridge" = Bridge-Mid, "Hi" = Upstream-High, "Mid" = Upstream-Mid, and "Lo" = Upstream-Low sample sources.

\subsection{Nested ANOVA of Early Data}

The results of the early analysis showed that, across 37 sampling events at four sites on 18 separate dates for the first year of the study, variation in E. coli counts between site-date sampling events accounted for $91.22 \%$ of the total observed variation among bacterial counts (Table 2). For each individual site (APP1, APP2, BUF1, and VAU14) and sampling date, variation in E. coli counts among the four sample locations (replicates: 8.66\%) was higher than the variation between the water column depths $(0.12 \%)$.

The results of the nested ANOVA comparing differences between counts of $E$. coli at different sample depths (Bridge-Mid; Upstream-High, -Mid, -Low) were not significant (Table 2, p = 0.3921). Only the differences between site-date combinations (blocks) were significant $\left(\mathrm{F}_{36,443}=122.4865, \mathrm{p}<0.0001\right)$; however, this study is not examining differences between the sites or sampling dates, so this finding has no relevance to the purpose of our study.

These results provided an early indication that there were no significant differences in E. coli counts among the four sampling locations/depths at each site (i.e., no indication was observed that stratification of bacteria occurred within the water column). Two lingering doubts, however, led us to continue sampling and to carry out an additional statistical analysis; 1 ) we could not be certain that log-transformation of the bacterial counts met all the assumptions of the parametric ANOVA carried out in the first phase, and 2) perhaps more importantly, we could not be certain whether stratification at one or more site-date combinations may have been masked by the lack of stratification at other site-date combinations in the overall analysis. We believed that local variations in 
Table 2. Two-level nested ANOVA of bacterial counts obtained from the water columns at each of the four stream sampling sites.

(a)

\begin{tabular}{ccccccc}
\hline & Source of Variation & df & SS & MS & F & p $\leq$ \\
\hline Data Blocks (Groups) & Among Groups (Level 1) & 36 & 104.4303 & 2.9008 & 122.49 & 0 \\
Components (Subgroups) & Among Subgroups (Level 2) & 11 & 2.6288 & 0.0237 & 1.04 & 0.3921 \\
Components (within Subgroups) & Within Subgroups & 396 & 6.7402 & 0.0228 & & \\
& Total & 443 & 113.7993 & & \\
\hline
\end{tabular}

(b)

\begin{tabular}{cccc}
\hline & \multicolumn{2}{c}{ Table of Variance Components } \\
& \multicolumn{2}{c}{ Average Component } \\
\hline & Variance & $\%$ of Total & \\
\hline Among Groups & 0.23908 & 91.22 & Sampling Event (Site, date combination) \\
Among Subgroups & 0.0003 & 0.12 & Vertical Stratification (Bridge-Mid; Upstrm-High, -Mid, -Low) \\
Within Subgroups & 0.0228 & 8.66 & Stream Location Replicates (Bridge, Upstream 1, 2, 3) \\
Total & 0.2622 & 100 & \\
\hline
\end{tabular}

hydrography might cause differences in stratification of bacterial presence within a particular stream site.

\subsection{Friedman Analysis of Complete Data Set}

Table 3 shows the results of the Friedman non-parametric analyses comparing bacterial counts obtained from the sampling depths for each of the four sampling locations for the entire data set. No differences were observed among bacterial counts within each block of data from the four sampling locations at each site. None of the Chi Square values of the analysis were significant, showing p values greater than 0.25 (Table 3). Accordingly, one data point (i.e., one sample) appears to be representative and suitable to describe the point distribution (bacterial counts) within any one block (date/site combination) for each of the four streams of this study.

\subsection{Relationship of Pooled Means and Variances}

Our data closely adhere to a Poisson distribution in that the variance values closely approximate the means. Figure 5 shows the relationship between log-transformed pooled means and variances for each of the 78 sampling events across the study. The data reveal a high, positive correlation $(r=0.8680)$ between mean and variance which relates to generally higher variability in $E$. coli counts when high concentrations of these bacteria are assessed and lower, more restricted variation when low E. coli concentrations are measured. In the context of water quality assessment, higher concentrations of E. coli can be associated with increased water flow in the drainage area that would occur during precipitation events and/or periods of increased surface run-off.

\section{Discussion}

Our data address both objectives for this study as they positively support our hypothesis that concentrations of the commonly used $E$. coli bacterial indicator are not stratified, but are homogenous within a generalized sampling area (of at least $50 \mathrm{~m}$ ) and throughout the accompanying water column for any particular sampling date for small, freshwater streams. A representative sample for a bacterial indicator such as $E$. coli for each of the streams of this study can be provided either from a bridge perch sampling position obtained by mechanical sampler device or from an in-stream position obtained manually if care is taken to insure for clean capture of water (e.g., with no detritus, benthic material, or surface film). Concentrations of E. coli do not differ meaningfully within the adjacent upstream water column of a bridge access point nor do E. coli numbers differ when obtained by either hand grab or mechanical method for any individual sample date/time. Current field sampling methods stress the importance of obtaining "clean" samples of moving environmental waters taken at or near the 
Table 3. Friedman one-way non-parametric ANOVA based on bacterial count rankings.

\begin{tabular}{|c|c|c|c|c|c|c|c|c|c|c|c|c|c|}
\hline \multirow[b]{3}{*}{ Site } & \multicolumn{9}{|c|}{ Sampling Locations (Treatments $\mathrm{k}=4$ ) } & & & & \\
\hline & \multicolumn{3}{|c|}{ Bridge } & \multicolumn{2}{|c|}{ Upstream-High } & \multicolumn{2}{|c|}{ Upstream-Mid } & \multicolumn{2}{|c|}{ Upstream-Low } & \multirow[b]{2}{*}{$\begin{array}{c}\text { Samples per } \\
\text { Treatment } \\
\text { (Replicates = m) }\end{array}$} & \multirow[b]{2}{*}{ Chi-Squared } & \multirow[b]{2}{*}{ df } & \multirow[b]{2}{*}{$\begin{array}{l}\text { Prob. Ho } \\
\text { Is True }\end{array}$} \\
\hline & $\begin{array}{l}\text { Number of } \\
\text { Events } \\
\text { (Blocks = b) }\end{array}$ & $\begin{array}{l}\text { Sum of } \\
\text { Ranks }\end{array}$ & $\begin{array}{l}\text { Mean } \\
\text { Rank }\end{array}$ & $\begin{array}{l}\text { Sum of } \\
\text { Ranks }\end{array}$ & $\begin{array}{l}\text { Mean } \\
\text { Rank }\end{array}$ & $\begin{array}{l}\text { Sum of } \\
\text { Ranks }\end{array}$ & $\begin{array}{l}\text { Mean } \\
\text { Rank }\end{array}$ & $\begin{array}{l}\text { Sum of } \\
\text { Ranks }\end{array}$ & $\begin{array}{l}\text { Mean } \\
\text { Rank }\end{array}$ & & & & \\
\hline APP1 & 24 & 471.5 & 6.549 & 486.5 & 6.757 & 418.0 & 5.806 & 496.0 & 6.889 & 3 & 4.048 & 3 & 0.2564 \\
\hline APP2 & 14 & 289.5 & 6.893 & 278.0 & 6.619 & 269.5 & 6.417 & 255.0 & 6.071 & 3 & 1.171 & 3 & 0.7600 \\
\hline BUF1 & 16 & 309.0 & 6.438 & 341.5 & 7.115 & 299.5 & 6.240 & 298.0 & 6.208 & 3 & 1.993 & 3 & 0.5738 \\
\hline VAU14 & 24 & 426.0 & 5.917 & 466.0 & 6.472 & 473.0 & 6.569 & 507.0 & 7.042 & 3 & 3.603 & 3 & 0.3076 \\
\hline $\begin{array}{l}\text { Total Sample } \\
\text { Events }\end{array}$ & 78 & & & & & & & & & & & & \\
\hline
\end{tabular}

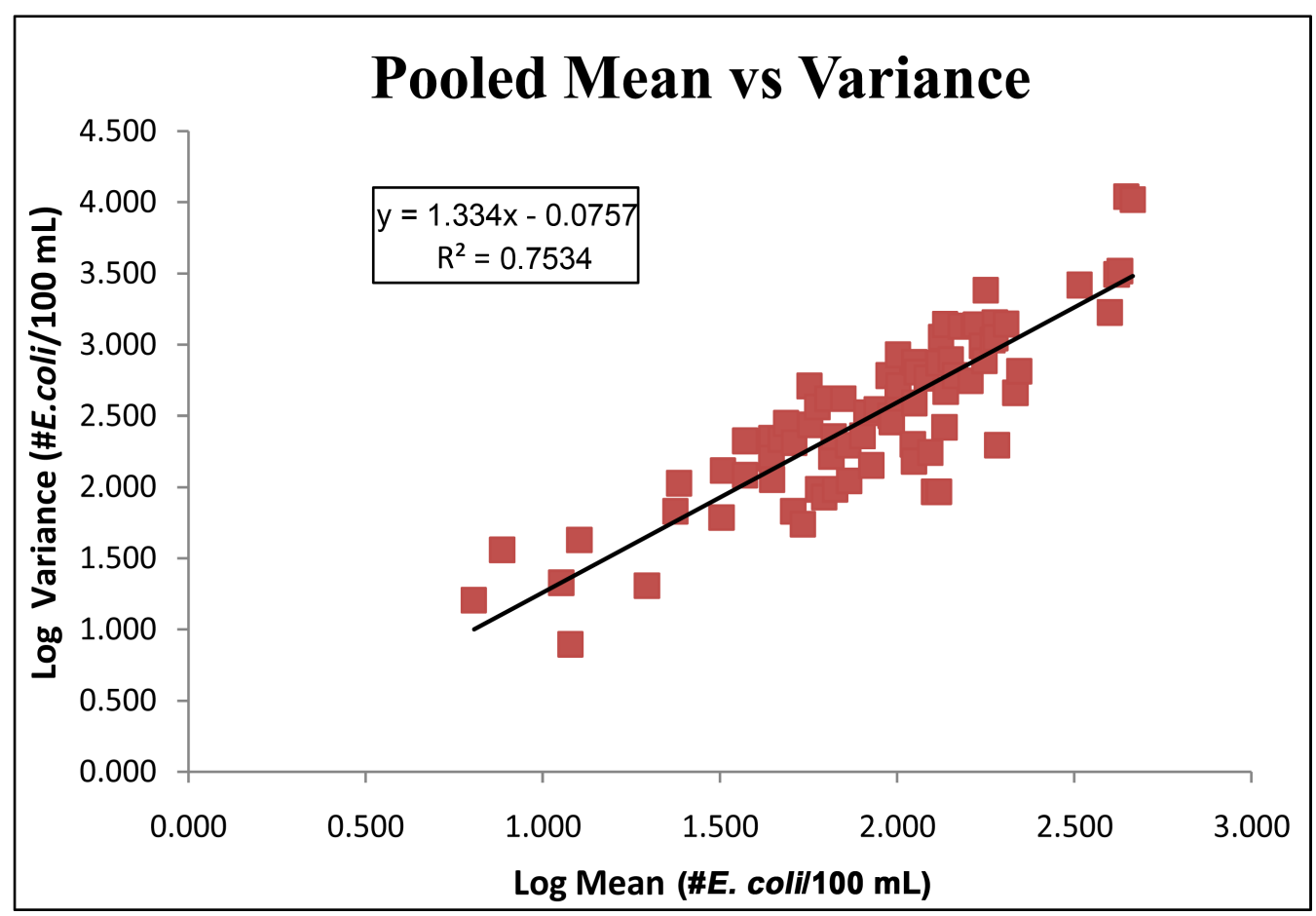

Figure 5. Correlation between pooled log-transformed means and variances for each of the individual site-date sampling events ( $\mathrm{n}=$ 78). The computed correlation coefficient $(\mathrm{r}=0.8680)$ reveals a strong, positive correlation between means and variation of $E$. coli counts per sampling site and date.

midpoint of the water column [32]. Although written mainly for physical and chemical analyses, the USGS National Field Manual [23] suggests several samples for bacterial assay should be taken within the cross-sectional area of a stream in order to be sufficiently representative and to lessen sample bias. Additionally, sampling protocols suggest water samples be taken from reaches upstream of bridges and other structures to avoid contaminating and/or toxic effects of surface runoff, etc. With the caveat of obtaining clean water samples near the main channel of the stream, these data reveal homogenous counts of indicator bacteria across multiple samples for a given sample date and homogeneity of counts either at or within $50 \mathrm{~m}$ upstream of a bridge perch.

To our knowledge, this is the first study to examine stratification of a bacterial water quality indicator within a small freshwater stream. These data reveal consistent homogeneity of E. coli concentrations at a variety of depths within the water column on any particular sampling date provided they are collected within or peripheral to the main channel. Whereas these data appear to contend the need for depth- and width-integrated approaches to sampling freshwaters proposed for decades [21] [26] [33] for bacterial samples, the authors of this report 
stress the importance of standards of sample quality (e.g., without disruption of stream bottom or inclusion of surface film) as reported in the literature [34] [35].

Although not reported here, our data also reveal within-event consistency of counts with respect to season and precipitation effects. Bacterial counts during cold or warm seasons varied to the extent reported by others in a variety of aquatic environments [36] [37], but the data did not reveal differences in count with respect to position in the water column for any specific sample date within any season. Precipitation events cause concomitant rises in counts of indicator bacteria by resuspension of bottom substrate particles [38]-[40] and increased runoff from adjacent land surfaces. Whenever precipitation occurred during or just prior to a sampling date for this study, a rise in E. coli indicators was observed across the cohort of samples for any one sample site, yet the variability of concentrations with respect to stream depth and location was insignificant.

It is imperative that environmental and public health agencies obtain reliable estimates of the bacteriologic quality of their nearby waterways to instill confidence in their constituent audiences and to insure for public safety. Our data suggest that a water sample for indicator bacterial assay taken with care on the same day/time from several different depths or from an adjacent or peripheral region along a moving water body is similar to one taken at the exact midpoint of the water column of the main channel. This finding allows some latitude with respect to choice of sampling locations for technicians, scientists, or other professionals involved in assessments of $E$. coli indicators of surface water quality for both urban as well as rural water monitoring. Our findings also suggest that rivers and streams showing high concentrations of indicator bacteria such as E. coli reveal such high counts homogenously throughout the cross-sectional area of the moving water body. Accordingly, the potential for human contact with fecally-derived pathogens (e.g., Salmonella, Campylobacter, Giardia, enteric viruses, etc.) for which these bacteria highly correlate/indicate may be equal throughout the water column.

\section{Acknowledgements}

This work was funded, in part, by grants from the Cook-Cole College of Arts and Sciences Undergraduate Research Support, Longwood University, and from the Virginia Department of Environmental Quality (VADEQ Contract numbers 14,309 and 14,733). Many thanks to W. Witschey for providing the map of our study sites. This work is dedicated to R. K. Riley and W. J. Vail, Emeritus Professors of Biology, Department of Biology, Frostburg State University.

\section{References}

[1] North, R.L., Khan, N.H., Ahsan, M., Prestie, C., Korber, D.R., Lawrence, J.R. and Hudson, J.J. (2014) Relation between Water Quality Parameters and Bacterial Indicators in a Large Prairie Reservoir: Lake Diefenbaker, Saskatchewan, Canada. Canadian Journal of Microbiology, 60, 243-249. http://dx.doi.org/10.1139/cjm-2013-0694

[2] Hong, H., Qiu, J. and Liang, Y. (2010) Environmental Factors Influencing the Distribution of Total and Fecal Coliform Bacteria in Six Water Storage Reservoirs in the Pearl River Delta Region, China. Journal of Environmental Sciences, 22, 663-668.http://dx.doi.org/10.1016/S1001-0742(09)60160-1

[3] Berdjeb, L., Ghiglione, J. and Jacquet, S. (2011) Bottom-Up versus Top-Down Control of Hypo- and Epilimnion FreeLiving Bacterial Community Structures in Two Neighboring Freshwater Lakes. Applied and Environmental Microbiology, 77, 3591- 3599. http://dx.doi.org/10.1128/AEM.02739-10

[4] Newton, R.J, Jones, S.E., Eiler, A., McMahon, K.D. and Bertilsson, S. (2011) A Guide to the Natural History of Freshwater Lake Bacteria. Microbiology and Molecular Biology Reviews, 75, 14-49. http://dx.doi.org/10.1128/MMBR.00028-10

[5] Mohandass, C., Bharathi, P. and Loka, A. (2003) Representation, Dispersion, and Variation of Bacterial Indicators in the Coastal Waters of Nagore (East Coast of India). Water Environment Research, 75, 66-72. http://dx.doi.org/10.2175/106143003X140845

[6] An, Y.J., Kampbell, D.H. and Breidenbach, G.P. (2002) Escherichia coli and Total Coliforms in Water and Sediments at Lake Marinas. Environmental Pollution, 120, 771-778.

[7] Sahl, J.W., Schmidt, R., Swanner, E.D., Mandernack, K.W., Templeton, A.S., Kieft, T.L., Smith, R.L., Sanford, W.E., Callaghan, R.L., Mitton, J.B. and Spear, J.R.. (2008) Subsurface Microbial Diversity in Deep-Granitic-Fracture Water in Colorado. Applied and Environmental Microbiology, 74, 143-152. http://dx.doi.org/10.1128/AEM.01133-07

[8] Curtis, T.P., Mara, D.D. and Silva, S.A. (1992) Influence of pH, Oxygen, and Humic Substances on Ability of Sunlight to Damage Fecal Coliforms in Waste Stabilization Pond Water. Applied and Environmental Microbiology, 58, 1335-1343.

[9] Jenkins, M., Fisher, D.S., Endale, D.M. and Adams, P. (2011) Comparative Die-off of Escherichia coli 0157: H7 and 
Fecal Indicator Bacteria in Pond Water. Environmental Science and Technology, 45, 1853-1858. http://dx.doi.org/10.1021/es1032019

[10] Khaengraeng, R. and Reed, R.H. (2005) Oxygen and Photoinactivation of Escherichia coli in UVA and Sunlight. Journal of Applied Microbiology, 99, 39-50. http://dx.doi.org/10.1111/j.1365-2672.2005.02606.x

[11] Sarkar, B.L., Nair, G.B., Banerjee, A.K. and Pal, S.C. (1985) Seasonal Distribution of Vibrio parahaemolyticus in Freshwater Environs and in Association with Freshwater Fishes in Calcutta. Applied and Environmental Microbiology, 49, 132-136.

[12] Ishii, S., Yan, T., Shively, D.A., Byappanahalli, M.N., Whitman, R.L. and Sadowsky, M.J. (2006) Cladophora (Chlorophyta) spp. Harbor Human Bacterial Pathogens in Nearshore Water of Lake Michigan. Applied and Environmental Microbiology, 72, 4545-4553. http://dx.doi.org/10.1128/AEM.00131-06

[13] Zeng, J., Bian, Y., Xing, P. and Wu, Q.L. (2012) Macrophyte Species Drive the Variation of Bacterioplankton Community Composition in a Shallow Freshwater Lake. Applied and Environmental Microbiology, 78, 177-184. http://dx.doi.org/10.1128/AEM.05117-11

[14] Staley, Z.R., Chase, E., Mitraki, C., Crisman, T.L. and Harwood, V.J. (2013) Microbial Water Quality in Freshwater Lakes with Different Land Use. Journal of Applied Microbiology, 115, 1240-1250. http://dx.doi.org/10.1111/jam.12312

[15] Staley, C., Reckhow, K.H., Lukasik, J. and Harwood, V.J. (2012) Assessment of Sources of Human Pathogens and Fecal Contamination in a Florida Freshwater Lake. Water Research, 46, 5799-5812. http://dx.doi.org/10.1016/j.watres.2012.08.012

[16] Nishimura, Y., Kim, C. and Nagata, T. (2005) Vertical and Seasonal Variations of Bacterioplankton Subgroups with Different Nucleic Acid Contents: Possible Regulation by Phosphorus. Applied and Environmental Microbiology, 71, 5828-5836. http://dx.doi.org/10.1128/AEM.71.10.5828-5836.2005

[17] Davis, K., Anderson, M.A. and Yates, M.V. (2005) Distribution of Indicator Bacteria in Canyon Lake, California. Water Research, 39, 1277-1288. http://dx.doi.org/10.1016/j.watres.2005.01.011

[18] Colombet, J., Sime-Ngando, T., Cauchie, H.M., Fonty, G., Hoffmann, L. and Demeure, G. (2006) Depth-Related Gradients of Viral Activity in Lake Pavin. Applied and Environmental Microbiology, 72, 4440-4445. http://dx.doi.org/10.1128/AEM.00021-06

[19] Wommack, K.E., Ravel, J., Hill, R.T., Chun, J. and Colwell, R.R. (1999) Population Dynamics of Chesapeake Bay Virioplankton: Total Community Analysis by Pulsed Field Gel Electrophoresis. Applied and Environmental Microbiology, 65, 231-240.

[20] Quilliam, R.S., Clements, K., Duce, C., Cottrill, S.B., Malham, S.K. and Jones, D.L. (2011) Spatial Variation of Waterborne Escherichia coli-Implications for Routine Water Quality Monitoring. Journal of Water and Health, 9, $734-737$. http://dx.doi.org/10.2166/wh.2011.057

[21] Edwards, T.K. and Glysson, G.D. (1988) Field Methods for Measurement of Fluvial Sediment. US Geological Survey Open-File Report 86-531.

[22] Ward, J.R. and Harr, C.A., Eds. (1990) Methods for Collection and Processing of Surface-Water and Bed-Material Samples for Physical and Chemical Analyses. US Geological Survey Open-File Report 90-140.

[23] Myers, D.N., Stoeckel, D.M., Bushon, R.N., Francy, D.S. and Brady, A.M.G. (2014) Fecal Indicator Bacteria (Ver. 2.1): US Geological Survey Techniques of Water-Resources Investigations, Book 9, Chapter A7, Section 7.1. http://pubs.water.usgs.gov/twri9A/

[24] Rodina, A.G. (1972) Methods in Aquatic Microbiology. University Park Press, Baltimore.

[25] Vereen, E., Lowrance, R.R., Cole, D.J. and Lipp, E.K. (2007) Distribution and Ecology of Campylobacters in Coastal Plain Streams (Georgia, United States of America). Applied and Environmental Microbiology, 73, 1395-1403. http://dx.doi.org/10.1128/AEM.01621-06

[26] American Public Health Association (APHA), American Water Works Association (AWWA) and Water Environment Federation (WEF) (1998) Microbiological Examination Section 9223 Enzyme Substrate Coliform Testing. In: Clesceri, L.S., Greenberg, A.E. and Eaton, A.D., Eds., Standard Methods for the Examination of Water and Wastewater, 20th Edition, American Public Health Association, Washington DC, 9/132-9/136.

[27] Leclerc, H., Mossel, D.A.A., Edberg, S.C. and Struijk, C.B. (2001) Advances in the Bacteriology of the Coliform Group: Their Suitability as Markers of Microbial Water Safety. Annual Review of Microbiology, 55, 201-234. http://dx.doi.org/10.1146/annurev.micro.55.1.201

[28] Niemala, S., Lee, J. and Fricker, C. (2003) A Comparison of the International Standards Organization Reference Method for the Detection of Coliforms and Escherichia coli in Water with a Defined Substrate Procedure. Journal of Applied Microbiology, 95, 1285-1292. http://dx.doi.org/10.1046/j.1365-2672.2003.02099.x 
[29] Buckalew, D.W., Hartman, L.J., Grimsley, G.A., Martin, A.E. and Register, K.M. (2006) A Long-Term Study Comparing Membrane Filtration with Colilert Defined Substrates in Detecting Fecal Coliforms and Escherichia coli in Natural Waters. Journal of Environmental Management, 80, 191-197. http://dx.doi.org/10.1016/j.jenvman.2005.08.024

[30] Sokal, R.R. and Rohlf, F.J. (1995) Biometry: The Principles and Practice of Statistics in Biological Research. 3rd Edition, W.H. Freeman and Co., New York.

[31] Conover, W.J. (1980) Practical Nonparametric Statistics. 2nd Edition, John Wiley \& Sons, New York.

[32] Jones, J. (2012) Standard Operating Procedures for Surface Water Quality Sampling. Pub. No. TB12-02, Arizona Department of Environmental Quality, Phoenix.

[33] Bordner, R.H. (1981) Microbiology: Methodology and Quality Assurance. Journal-Water Pollution Control Federation, 53, 1098-1107.

[34] Jamieson, R.C., Joy, D.M., Lee, H., Kostaschuk, R. and Gordon, R.J. (2005) Re-Suspension of Sediment-Associated Escherichia coli in a Natural Stream. Journal of Environmental Quality, 34, 581-589. http://dx.doi.org/10.2134/jeq2005.0581

[35] Byappanahalli, M.N., Whitman, R.L., Shively, D.A., Sadowsky, M.J. and Ishii, S. (2006) Population Structure, Persistence, and Seasonality of Autochthonous Escherichia coli in Temperate, Coastal Forest Soil from a Great Lakes Watershed. Environmental Microbiology, 8, 504-513. http://dx.doi.org/10.1111/j.1462-2920.2005.00916.x

[36] Sherer, B.M., Miner, J.R., Moore, J.A. and Buckhouse, J.C. (1992) Indicator Bacterial Survival in Stream Sediments. Journal of Environmental Quality, 21, 591-595. http://dx.doi.org/10.2134/jeq1992.00472425002100040011x

[37] Bunn, S.E., Davies, P.M. and Mosisch, T.D. (1999) Ecosystem Measures of River Health and Their Response to Riparian Catchment Degradation. Freshwater Biology, 41, 333-345. http://dx.doi.org/10.1046/j.1365-2427.1999.00434.x

[38] Van Donsel, D.J., Geldreich, E.E. and Clarke, N.A. (1967) Seasonal Variations in Survival of Indicator Bacteria in Soil and Their Contribution to Storm-Water Pollution. Applied and Environmental Microbiology, 15, 1362-1370.

[39] Hyland, J.L., Balthis, W.L., Engle, V.D., Long, E.R., Paul, J.F., Summers, J.K. and Van Dolah, R.F. (2003) Incidence of Stress in Benthic Communities along the US Atlantic and Gulf of Mexico Coasts within Different Ranges of Sediment Contamination from Chemical Mixtures. Environmental Monitoring and Assessment, 81, 149-161. http://dx.doi.org/10.1023/A:1021325007660

[40] Wilkes, G., Edge, T., Gannon, V., Jokinen, C., Lyautey, E., Medeiros, D. and Lapen, D.R. (2009) Seasonal Relationships among Indicator Bacteria, Pathogenic Bacteria, Cryptosporidium Oocysts, Giardia Cysts, and Hydrological Indices for Surface Waters Within an Agricultural Landscape. Water Research, 43, 2209-2223. http://dx.doi.org/10.1016/j.watres.2009.01.033 